\title{
Evaluasi Pengendalian Schistosomiasis oleh Lintas Sektor Tahun 2018
}

\author{
EVALUATION OF MULTI-SECTORAL SCHISTOSOMIASIS CONTROL IN 2018
}

Hayani Anastasia*, Junus Widjaja, Anis Nurwidayati, Samarang, Intan Tolistiawati, Meiske Koraag, Malonda Maksud, Yuyun Srikandi, Risti, Leonardo, dan Mujiyanto

Balai Litbangkes Donggala

Jl. Masitudju 58, Labuan Panimba, Donggala, Sulawesi Tengah 92121, Indonesia

*Email : hayani.as@gmail.com

Submitted : 25-06-2019, Revised: 16-09-2019, Revised:11-10-2019, Accepted : 27-11-2019

\begin{abstract}
In Indonesia, schistosomiasis is caused by Schistosoma japonicum with Oncomelania hupensis lindoensis as the intermediate host. Schistosomiasis can infect humans and all species of mammals. In order to achieve schistosomiasis elimination by 2020, schistosomiasis control including environmental management, has been carried out by multi-sectors. A cross-sectional study was conducted in 2018 to evaluate multi-sectoral schistosomiasis control programs. Data were collected by in-depth interviews with stakeholders, stool survey, snail survey, field observation, and document reviews. About $53.6 \%$ of control programs targeted in the schistosomiasis control roadmap were not achieved. Moreover, there was no significant difference between the number of foci area prior to the control programs and that of after the control programs completed in 2018. In addition, the prevalence of schistosomiasis in the humans was $0-5.1 \%$ and in mammals was in the range of 0 to $10 \%$. In order to overcome the problems, establishment of a policy concerning schistosomiasis as a priority program beyond the Ministry of Health is needed. Innovative health promotion with interactive media is also needed to be applied. Nonetheless, the schistosomiasis work teams need to be more active to collaborate with other sectors and the Agency of Regional Development of Central Sulawesi Province as the leading sector.
\end{abstract}

Keywords: schistosomiasis, control program, multi-sector, evaluation

\begin{abstract}
Abstrak
Schistosomiasis di Indonesia disebabkan oleh cacing trematoda jenis Schistosoma japonicum dengan hospes perantara keong Oncomelania hupensis lindoensis. Schistosomiasis selain menginfeksi manusia, juga menginfeksi semua jenis mamalia. Untuk mencapai eliminasi schistosomiasis pada tahun 2020 dilakukan pengendalian schistosomiasis oleh lintas sektor termasuk di dalamnya pelaksanaan manajemen lingkungan. Upaya pencapaian eliminasi schistosomiasis dilakukan terutama dengan manajemen lingkungan yang direncanakan bersama oleh lintas sektor. Penelitian cross sectional dilakukan untuk mengevaluasi pelaksanaan program pengendalian schistosomiasis oleh lintas sektor dan implementasi pengendalian schistosomiasis terpadu untuk eliminasi schistosomiasis. Pengumpulan data dilakukan dengan wawancara mendalam stakeholder, review dokumen, survei keong, observasi lapangan, dan survei tinja. Hasil penelitian menunjukkan 53,6\% kegiatan yang direncanakan dalam roadmap tidak terlaksana tahun 2018. Perbandingan jumlah fokus yang ditemukan pada akhir tahun 2018 tidak jauh berbeda dengan sebelum kegiatan pengendalian. Prevalensi schistosomiasis pada manusia tahun 2018 berkisar $0-5,1 \%$. Prevalensi schistosomiasis pada hewan berkisar $0-10 \%$. Untuk mengatasi permasalahan yang dihadapi perlu adanya rekomendasi kebijakan schistosomiasis sebagai kegiatan prioritas di kementerian di luar kesehatan sehingga memungkinkan perencanaan kegiatan yang lebih terarah oleh lintas sektor. Selain itu perlu dilakukan promosi kesehatan yang lebih inovatif dengan menggunakan media yang lebih menarik dan interaktif. Peranan aktif kelompok kerja tim pengendalian schistosomiasis perlu ditingkatkan dengan Bappeda sebagai leading sector.
\end{abstract}

Kata kunci: schistosomiasis, pengendalian, lintas sektor, evaluasi 


\section{PENDAHULUAN}

Schistosomiasis yang disebabkan oleh Schistosoma japonicum selain menginfeksi manusia juga menginfeksi semua jenis mamalia baik hewan peliharaan maupun binatang liar. Schistosomiasis di Indonesia hanya ditemukan di Provinsi Sulawesi Tengah, yaitu di Dataran Tinggi Napu dan Dataran Tinggi Bada, Kabupaten Poso serta Dataran Tinggi Lindu, Kabupaten Sigi. Pengendalian schistosomiasis telah dilakukan sejak tahun 1974 tetapi hanya di daerah yang terbatas. Pengobatan dengan Niridazole telah dipakai untuk mengobati penderita schistosomiasis sebelum ditemukan praziquantel, namun tidak efektif dan Niridazole sangat toksik. Setelah ditemukan praziquantel, dilakukan pengobatan massal di Dataran Tinggi Lindu dan Napu semenjak tahun 2000. Pemberantasan keong dilakukan dengan berbagai cara mekanik dan kimia. Pengendalian secara mekanik dilakukan dengan perbaikan saluran air di daerah fokus, pengeringan daerah fokus, dan penimbunan; pengendalian secara kimia dilakukan dengan penyemprotan baylucide pada daerah fokus. ${ }^{2}$

Sejak proyek Central Sulawesi Integrate Area Development and Conservation Project (CSIADCP) berakhir pada tahun 2004, prevalensi schistosomiasis berfluktuasi. Prevalensi schistosomiasis pada manusia sebesar lebih dari 1\% pada tahun 2005 dan 2006. Pada tahun 2009, prevalensi schistosomiasis di Napu dan Lindu meningkat menjadi masingmasing 3,8\% dan 2,5\%. ${ }^{3}$ Pada tahun 2008, dua desa di Bada dikonfirmasi sebagai daerah endemis baru schistosomiasis. ${ }^{4}$ Prevalensi kasus schistosomiasis di Lindu pada tahun 2011 - 2015 yaitu berturut-turut $0,8 \%, 0,76 \%, 0,71 \%, 1,61 \%$ dan 1,3\%. Prevalensi di Napu tahun $2011-2015$ yaitu masing-masing $0,31 \%, 1,43 \%, 2,25 \%$, $0,8 \%, 1,9 \%{ }^{2,5}$

Hasil penelitian pada keong dan mamalia menunjukkan bahwa pada tahun 2015, infection rate pada keong adalah sebesar 3,4\% di Lindu dan $4,8 \%$ di Napu sedangkan infection rate pada tikus adalah sebesar $16 \%$ di Lindu dan 7,3\% di Napu. ${ }^{2,5}$ Prevalensi schistosomiasis pada kerbau berkisar antara 36,4-47,5\%; pada sapi antara $16,7-33,3 \%$; pada babi antara $8,3-20 \%$; dan pada anjing antara $8,3-20 \% .{ }^{6,7}$
Program pengendalian yang dilakukan hingga saat ini belum dapat menekan angka kejadian schistosomiasis, karena adanya reinfeksi dari berbagai reservoar, diantaranya tikus, ternak masyarakat, termasuk hewan liar, bahkan masyarakat sendiri sebagai pembawa. Masalah yang dihadapi dalam program pengendalian schistosomiasis antara lain: (1) pengendalian keong dan daerah fokus tidak dilakukan secara komprehensif dan teratur, (2) pengendalian schistosomiasis pada hewan masih sangat terbatas, (3) pengetahuan dan kesadaran petani masih sangat terbatas dan mereka kurang memahami bagaimana mencegah terjadinya infeksi schistosomiasis, serta (4) diagnosis hanya menggunakan Kato-Katz, yang kurang sensitif pada daerah endemis rendah. ${ }^{3}$

Pemberantasan schistosomiasis dilakukan sejak tahun 1982 secara intensif. Periode pertama berlangsung sejak 1982-1986 dengan kegiatan berupa pengobatan massal, survei tinja, dan survei tikus setiap enam bulan. Pada periode ini prevalensi menurun secara signifikan dan partisipasi masyarakat pada periode ini masih sangat bagus. Pengendalian periode kedua berlangsung pada tahun 1986-1990 dengan kegiatan berupa pengobatan selektif. Sektor pertanian juga melakukan pengelolaan lahan sehingga dapat mengeliminasi beberapa daerah fokus, program transmigrasi, dan memobilisasi peran serta masyarakat. Pengendalian periode ketiga berlangsung pada tahun 1991-1993, dengan kegiatan yang lebih terintegrasi. Pada periode ini sektor kesehatan bukan lagi sebagai leading sector, akan tetapi digantikan oleh Bappeda. Pada periode ini juga dibentuk Kelompok Kerja Schistosomiasis. $^{2}$

Pengendalian schistosomiasis periode keempat berlangsung pada tahun 1993-1998, dengan adanya kelompok kerja schistosomiasis yang diberi nama integrated development project. Periode selanjutnya yaitu tahun 19982005 yaitu dengan dimulainya CSIADCP (Central Sulawesi Integrated Area Development and Conservation Project). Pada periode ini pengendalian schistosomiasis sangat intensif peran lintas sektor sangat baik, yaitu: kesehatan, pertanian, pekerjaan umum, transmigrasi, Program Kesejahteraan Keluarga (PKK), dan peternakan. $^{2}$ Pengendalian keong dilakukan secara mekanik dan kimia. Pengendalian secara 
mekanik dilakukan dengan perbaikan saluran air di daerah fokus, pengeringan daerah fokus, dan penimbunan. Pengendalian secara kimia dilakukan dengan penyemprotan baylucide pada daerah fokus. ${ }^{2}$

Pemetaan fokus keong O.hupensis lindoensis pada tahun 2008 berhasil menemukan fokus keong O.hupensis lindoensis sebanyak 129 fokus, yang tersebar pada 16 sub desa dari 4 desa yang ada di wilayah dataran tinggi Lindu. Total fokus tersebut terdiri dari 120 fokus yang masih aktif, 68 fokus tidak aktif dan 1 fokus baru. Pada tahun 2008 fokus yang berhasil ditemukan di wilayah dataran Tinggi Napu sebanyak 369 fokus, terdiri atas 170 fokus aktif, 166 fokus tidak aktif dan 33 fokus baru. Sebanyak 49 fokus lama tidak ditemukan lagi. Pada tahun 2008 dilakukan juga pemetaan fokus keong $O$. hupensis lindoensis di wilayah Dataran Tinggi Bada Kabupaten Poso, dan hasilnya, ditemukan 21 fokus baru yang tersebar di tiga desa (Kageroa, Tomehipi, dan Lengkeka) di wilayah Kecamatan Lore Barat. ${ }^{4}$

Peran serta aktif masyarakat sangat penting dalam pengendalian schistosomiasis. Pada tahun 1986-1990, Program Kesejahteraan Keluarga (PKK) memegang peranan penting dalam meningkatkan partisipasi masyarakat dengan cara membentuk dan melatih kader untuk membantu petugas kesehatan dalam pembagian dan pengumpulan pot tinja masyarakat, partisipasi masyarakat dalam pengobatan, serta meningkatkan kesadaran masyarakat melalui penyuluhan kesehatan. Peran serta masyarakat pada fase kedua sangat aktif sehingga dapat menurunkan prevalensi schistosomiasis. Setelah prevalensi menurun, maka kasus kronis sudah jarang ditemukan di masyarakat, hal ini menyebabkan menurunnya kesadaran masyarakat untuk berpartisipasi dalam pengendalian schistosomiasis, sehingga menyebabkan prevalensi schistosomiasis kembali meningkat. Peningkatan kasus schistosomiasis juga disebabkan kurang terintegrasinya peran lintas sektor dalam pengendalian schistosomasis. Lintas sektor melaksanakan kegiatan sesuai tugas pokok masing-masing, dan belum sesuai dengan saran pengendalian schistosomiasis.

Untuk mencapai eliminasi keong perantara $O$. hupensis lindoensis melalui peran lintas sektor di Sulawesi Tengah, akan dilaksanakan penelitian dalam tiga tahap, yaitu: pada tahun pertama akan dilaksanakan pemetaan habitat keong perantara schistosomiasis di Dataran Tinggi Lindu, Napu, Besoa, dan Bada. Tahun kedua akan dilakukan evaluasi program pengendalian untuk eliminasi schistosomiasis di daerah endemis dan implementasi daerah percontohan program pengendalian schistosomiasis untuk akselerasi pencapaian eliminasi schistosomiasis tahun 2020 dan pada tahun ketiga akan dilakukan model pengendalian schistosomiasis terpadu di salah satu wilayah endemis.

Dalam rangka pencapaian eliminasi schistosomiasis pada tahun 2020 dilakukan pengendalian schistosomiasis oleh lintas sektor termasuk di dalamnya pelaksanaan manajemen lingkungan yang dilakukan berdasarkan hasil pemetaan daerah fokus yang dilakukan oleh Balai Litbang P2B2 Donggala pada tahun 2016 dan 2017. Kegiatan dikoordinir oleh Bappenas dan Bappeda dengan lintas sektor yang terlibat dalam kegiatan pengendalian schistosomiasis adalah Dinas Kesehatan, Dinas PU dan Perumahan, Dinas Tanaman Pangan Hortikultura \& Perkebunan, Dinas Ketahanan Pangan dan Perikanan, Dinas Peternakan dan Kesehatan Hewan, Dinas PMD, Dinas Pendidikan dan Kebudayaan, serta Taman Nasional Lore Lindu.

Untuk mengetahui kemajuan perencanaan kegiatan pengendalian dan keberhasilan kegiatan pengendalian schistosomiasis, perlu dilakukan penelitian evaluasi program pengendalian schistosomiasis di daerah endemis. Evaluasi dilakukan dengan cara evaluasi proses pelaksanaan intervensi manajemen lingkungan yang dilakukan oleh lintas sektor maupun evaluasi pengendalian schistosomiasis pada manusia dan hewan.

\section{BAHAN DAN METODE}

Penelitian dilakukan di Dataran Tinggi Napu, Lindu, dan Bada pada Januari sampai Desember 2018. Penelitian ini merupakan evaluasi proses dengan desain cross sectional. Pengumpulan data dilakukan dengan:

1. Wawancara mendalam dilakukan pada pelaksana kegiatan pengendalian schistosomiasis di masing-masing Organisasi Perangkat 
Daerah (OPD), kepala Puskesmas, Kades, petugas laboratorium schistosomiasis, PKK, kader; Kementerian Kesehatan (P2P), PUPR, Kelautan, KLHK, Pertanian, dan Peternakan terkait pelaksanaan kegiatan pengendalian. Wawancara dilakukan dengan daftar topik pertanyaan tentang pengendalian schistosomiasis.

2. Review dokumen perencanaan kegiatan dan anggaran kegiatan pengendalian schistosomiasis tahun 2018 masing-masing OPD. Review dokumen ini bertujuan untuk melihat kesesuaian rencana kegiatan dengan roadmap pengendalian schistosomiasis, rencana aksi manajemen lingkungan sesuai daerah fokus, dan pelaksanaan manajemen lingkungan oleh masing-masing OPD.

3. Observasi dan review pelaksanaan kegiatan pengendalian schistosomiasis oleh OPD. Observasi dilakukan pada pelaksanaan kegiatan manajemen lingkungan untuk mengurangi daerah fokus oleh OPD sesuai perencanaan. Observasi dan review juga dilakukan pada kegiatan pengendalian schistosomiasis yang bukan merupakan kegiatan manajemen lingkungan, seperti pengobatan pada manusia dan hewan, surveilans schistosomiasis, survei tinja (berapa pot yg dibagi, pengambilan tinja, bagaimana sensus awal, cara pembagian pot, bagaimana pemberdayaan kader, keterlibatan PKM, kader), survei keong dan tikus. Observasi dan review kegiatan dilakukan dengan membandingkan kesesuaian pelaksanaan kegiatan dengan perencanaan kegiatan dan metode baku yang berlaku untuk pelaksanaan survei.

4. Survei keong; dilakukan di daerah fokus yang ditemukan pada tahun 2016 dan 2017 yang telah dilakukan pengendalian manajemen lingkungan oleh lintas sektor. Pengambilan sampel keong dengan metode man per minute. Untuk menentukan Infection Rate (IR), keong diperiksa apakah keong mengandung serkaria di bawah mikroskop dengan metode "crushing".

5. Survei tinja manusia: survei tinja manusia dilakukan oleh Dinas Kesehatan Provinsi dan Kabupaten di 28 desa endemis schistosomiasis. Selain itu Balai Litbangkes Donggala juga melakukan survei tinja di 6 desa endemis. Survai tinja dilakukan secara pada penduduk yang berumur 2 tahun ke atas di daerah endemis. Pengambilan sampel tinja penduduk dilakukan selama tiga hari berturut-turut ( 3 kali pengambilan sampel) untuk setiap orang. Setiap sampel tinja dibuat 3 sediaan (preparat) dengan menggunakan metoda modifikasi Kato Katz yang kemudian diperiksa di bawah mikroskop. Sampel dinyatakan negatif (-) apabila 3 hari berturut-turut tidak ditemukan telur $S$. japonicum dalam tinjanya.

6. Survei tinja hewan: pengambilan sampel dilakukan pada sapi, kerbau, kuda, babi dan anjing dengan jumlah sampel minimal 10 ekor per desa. Sampel tinja yang diambil adalah tinja segar yang baru jatuh di atas permukaan tanah. Pemeriksaan sampel tinja dilakukan dengan menggunakan metode sentrifugasi formalin-eter sesuai dengan standar dari WHO.

\section{HASIL}

Hasil penelitian menunjukkan 53,6\% kegiatan yang direncanakan dalam roadmap tidak terlaksana pada tahun 2018. Angka ini diperoleh dari perbandingan seluruh jumlah kegiatan pengendalian schistosomiasis yang dilaksanakan oleh seluruh Organisasi Perangkat Daerah (OPD) terkait pada tahun 2018 dengan seluruh kegiatan pengendalian schistosomiasis pada tahun 2018 yang tercantum dalam roadmap pengendalian schistosomiasis. Kegiatan 2018 yang paling banyak tidak terlaksana adalah kegiatan pengembangan kapasitas seperti workshop dan pelatihan. Lintas sektor berusaha mengatasi ini dengan cara mengalihkan lokasi kegiatan yang dilakukan, seperti kegiatan pembuatan saluran air yang sebelumnya direncanakan di desa non-endemis dipindahkan ke desa endemis schistosomiasis.

Dari 10 intervensi kunci yang termuat dalam roadmap pengendalian schistosomiasis hanya dua intervensi kunci yang mencapai target hasil berdasarkan roadmap. Pengobatan massal pada manusia mencapai target $100 \%$, demikian pula surveilans keong perantara mencapai 98\%, melebihi target 51\% pada tahun 2018 (Tabel 1). 
Tabel 1. Capaian Kegiatan Pengendalian Schistosomiasis Tahun 2018 Berdasarkan Intervensi Kunci Roadmap Pengendalian Schistosomiasis

\begin{tabular}{|c|c|c|c|}
\hline Intervensi Kunci & Indikator Capaian Hasil & Target Hasil 2018 & Realisasi Hasil 2018 \\
\hline $\begin{array}{l}\text { Pengobatan massal pada manu- } \\
\text { sia } 1 \text { kali setahun }\end{array}$ & $\begin{array}{l}\text { Proporsi jumlah penduduk minum obat PZ per } \\
\text { tahun }\end{array}$ & $100 \%$ & $91,9 \%$ \\
\hline $\begin{array}{l}\text { Pengobatan massal pada hewan } \\
2 \text { kali setahun }\end{array}$ & $\begin{array}{l}\text { Proporsi jumlah ternak besar (sapi, kerbau, } \\
\text { kuda) yang diobati PZ per semester }\end{array}$ & $100 \%$ & $25 \%$ \\
\hline $\begin{array}{l}\text { Modifikasi lingkungan terpadu } \\
\text { lintas sektor }\end{array}$ & $\begin{array}{l}\text { Jumlah desa yang menerima modifikasi } \\
\text { lingkungan terpadu }\end{array}$ & 23 desa & 17 desa \\
\hline $\begin{array}{l}\text { Pemberantasan keong secara } \\
\text { kimiawi }\end{array}$ & $\begin{array}{l}\text { Luas fokus yang menerapkan pemberantasan } \\
\text { kimiawi }\end{array}$ & $330.383 \mathrm{~m} 2$ & $323.402 \mathrm{~m} 2$ (222 fokus) \\
\hline $\begin{array}{l}\text { Penyediaan air minum, sanitasi, } \\
\text { hygiene }\end{array}$ & $\begin{array}{l}\text { Kumulatif cakupan KK dengan akses air minum } \\
\text { dan sanitasi layak dan berkelanjutan }\end{array}$ & $\begin{array}{l}100 \% \text { akses dengan sam- } \\
\text { bungan rumah } \\
85 \% \text { akses sanitasi layak }\end{array}$ & $\begin{array}{l}50 \% \text { akses dengan } \\
\text { sambungan rumah } \\
25 \% \text { akses sanitasi layak }\end{array}$ \\
\hline $\begin{array}{l}\text { Penyediaan MCK Umum di dae- } \\
\text { rah fokus }\end{array}$ & $\begin{array}{l}\text { Kumulatif MCK yang sehat dan terawat di areal } \\
\text { fokus }\end{array}$ & 172 unit $\mathrm{MCK}$ & 60 unit MCK \\
\hline $\begin{array}{l}\text { Pengelolaan hewan ternak } \\
\text { (termasuk pembinaan kelompok } \\
\text { ternak) }\end{array}$ & $\begin{array}{l}\text { Proporsi jumlah ternak besar (sapi, kerbau, } \\
\text { kuda) yang terhindar dari kontak dengan fokus }\end{array}$ & $50 \%$ & $0 \%$ \\
\hline $\begin{array}{l}\text { Surveilans pada manusia, hewan, } \\
\text { keong perantara }\end{array}$ & $\begin{array}{l}\text { Proporsi jumlah sampel pemeriksaan terhadap } \\
\text { jumlah populasi (manusia dan hewan) dan luas } \\
\text { fokus (keong) }\end{array}$ & $\begin{array}{l}100 \% \text { (hewan) } \\
51 \% \text { (keong) }\end{array}$ & $\begin{array}{l}\text { Manusia } 80,6 \% \\
\text { Hewan } 70 \% \\
\text { Keong } 98 \%\end{array}$ \\
\hline $\begin{array}{l}\text { Kampanye perubahan perilaku } \\
\text { dan peningkatan partisipasi ma- } \\
\text { syarakat }\end{array}$ & $\begin{array}{l}\text { Jumlah desa aktif melakukan kampanye dengan } \\
\text { materi dan metode KIE berbasis pendekatan one } \\
\text { health }\end{array}$ & 28 desa & $\begin{array}{l}3 \text { desa (Desa Tuare, } \\
\text { Tomehipi, Tomado) }\end{array}$ \\
\hline $\begin{array}{l}\text { Koordinasi multi sektor dan } \\
\text { monev terpadu secara intensif }\end{array}$ & Cakupan kegiatan dengan capaian sesuai target & $80 \%$ & $36 \%$ \\
\hline
\end{tabular}

Tabel 2. Perbandingan Jumlah Fokus Keong Perantara Schistosomiasis Tahun 2017 dan 2018

\begin{tabular}{|c|c|c|c|}
\hline Desa & Tahun 2017 & Tahun 2018 & Keterangan \\
\hline Dodolo & 34 & 20 & $\begin{array}{l}\text { Di awal penelitian ditemukan } 8 \text { fokus baru; pada saat post- ditemukan } 2 \text { fokus baru: } 19 \\
\text { fokus hilang saat post- karena kering, } 2 \text { fokus dibuat saluran air, dan } 1 \text { fokus dibuat kebun } \\
\text { kacang; } 10 \text { fokus }+(\mathrm{IR}=0,4-20 \%)\end{array}$ \\
\hline Kaduwa & 11 & 7 & $\begin{array}{l}\text { Di awal penelitian ditemukan } 2 \text { fokus baru; fokus hilang saat post- karena kering, } 3 \text { fokus } \\
(+)(\mathrm{IR}=3,8-40 \%)\end{array}$ \\
\hline Tomehipi & 8 & 7 & 1 fokus dibuat irigasi, semua fokus (-) \\
\hline Tuare & 8 & 7 & 1 fokus kering; semua fokus (-) \\
\hline Tomado & 15 & 7 & Tahun 2017: saat pre- 1 fokus tergabung ke Langko. Post: 4 fokus $(+) ; \mathrm{IR}=5,8-42,8 \%$ \\
\hline Langko & 1 & 2 & $\begin{array}{l}1 \text { fokus tdk ditemukan keong, } 1 \text { fokus }(-), 1 \text { fokus }(+) \text {; IR=4,3\%; tambahan } 1 \text { fokus karena } \\
\text { perubahan batas desa dari Tomado }\end{array}$ \\
\hline Wanga & 5 & 4 & 1 fokus kering \\
\hline Alitupu & 23 & 21 & 2 fokus kering \\
\hline Winowanga & 39 & 38 & 1 fokus kering \\
\hline Anca & 12 & 12 & \\
\hline Lengkeka & 5 & 3 & 2 fokus $(+)(\mathrm{IR}=5,7-7,6 \%), 2$ fokus kering \\
\hline Kageroa & 4 & 3 & semua fokus (-), 1 fokus kering \\
\hline
\end{tabular}

Keterangan IR: Infection Rate

Walaupun $53,6 \%$ yang direncanakan dalam roadmap tidak terlaksana, beberapa lintas sektor yang sebelumnya tidak termasuk dalam roadmap, ikut terlibat dalam kegiatan pengendalian schistosomiasis di tahun 2018. Lintas sektor tersebut adalah Dinas Pendidikan, Dinas Lingkungan Hidup, dan Balai Wilayah Sungai III (BWS III).
Perbandingan jumlah fokus yang ditemukan pada akhir tahun 2018 tidak berbeda dengan sebelum kegiatan pengendalian. Fokus yang tidak ditemukan keong disebabkan karena kondisi kering secara alami karena cuaca bukan karena kegiatan pengendalian. Kondisi fokus seperti ini biasanya akan ditemukan kembali keong apabila fokus lembab. (Tabel 2). 
Tabel 3. Prevalensi Schistosomiasis pada Manusia Tahun 2018

\begin{tabular}{|c|c|c|c|c|c|}
\hline Desa & $\begin{array}{c}\text { Jumlah Penduduk } \\
>2 \text { Tahun }\end{array}$ & $\begin{array}{c}\text { Jumlah Penduduk } \\
\text { Diperiksa }\end{array}$ & $\begin{array}{l}\text { Jumlah Positif } \\
\text { Schistosomiasis }\end{array}$ & $\begin{array}{c}\text { Prevalensi } \\
(\%)\end{array}$ & $\begin{array}{c}\text { Respon Rate } \\
(\%)\end{array}$ \\
\hline \multicolumn{6}{|l|}{ Napu } \\
\hline Banyusari & 557 & 498 & 2 & 0,4 & 89,4 \\
\hline Sedoa & 1050 & 948 & 4 & 0,4 & 90,3 \\
\hline Kaduwa & 853 & 774 & 1 & $0,1(0)$ & $90,7(78,4)$ \\
\hline Alitupu & 2276 & 2090 & 7 & $0,3(2,9)$ & $91,8(54,9)$ \\
\hline Tamadue & 993 & 938 & 8 & 0,9 & 94,5 \\
\hline Mekarsari & 1333 & 1204 & 5 & 0,4 & 90,3 \\
\hline Maholo & 1142 & 1053 & 2 & 0,2 & 92,2 \\
\hline Winowanga & 997 & 877 & 8 & $0,9(0)$ & $97,9(47,6)$ \\
\hline Dodolo & 368 & 338 & 7 & $2,1(1,3)$ & $91,9(72,3)$ \\
\hline Watutau & 926 & 755 & 0 & 0 & 81,5 \\
\hline Wanga & 294 & 252 & 1 & $0,4(0)$ & $85,7(30)$ \\
\hline Kalimago & 546 & 497 & 4 & 0,8 & 91 \\
\hline Siliwanga & 520 & 427 & 0 & 0 & 82,1 \\
\hline Betue & 358 & 298 & 0 & 0 & 83,2 \\
\hline Torire & 407 & 373 & 0 & 0 & 91,7 \\
\hline Watumaeta & 2374 & 2153 & 4 & 0,2 & 90,7 \\
\hline Wuasa & 2506 & 1755 & 0 & 0 & 70 \\
\hline \multicolumn{6}{|l|}{ Bada } \\
\hline Kageroa & 318 & 264 & 4 & $1,5(0)$ & $83,0(44,8)$ \\
\hline Tomehipi & 245 & 217 & 0 & $0(0)$ & $88,6(83,6)$ \\
\hline Lengkeka & 751 & 410 & 0 & $0(0)$ & $54,6(59,4)$ \\
\hline Tuare & 434 & 341 & 2 & $0,6(0)$ & $78,6(90,6)$ \\
\hline Kolori & 430 & 330 & 0 & 0 & 76,7 \\
\hline Lelio & 341 & 284 & 0 & 0 & 83,3 \\
\hline \multicolumn{6}{|l|}{ Lindu } \\
\hline Anca & 579 & 364 & 4 & $1,1(0)$ & $62,9(51,4)$ \\
\hline Tomado & 1011 & 649 & 4 & $0,6(0)$ & $64,2(54,3)$ \\
\hline Puroo & 567 & 401 & 6 & 1,5 & 70,7 \\
\hline Langko & 582 & 234 & 12 & $5,1(0)$ & $40,2(57,2)$ \\
\hline Olu & 1504 & 660 & 1 & 0,2 & 43,9 \\
\hline
\end{tabular}

Sumber: Dinas Kesehatan Provinsi

( ) : Data hasil survei langsung Balitbangkes Donggala dengan sampel penduduk yang belum mengumpulkan tinja pada surveilans Dinkes Provinsi

Prevalensi: jumlah positif schistosomiasis/jumlah penduduk diperiksa

Respon rate: jumlah penduduk diperiksa/jumlah penduduk $>2$ tahun

Tabel 4. Prevalensi Schistosomiasis pada Hewan Tahun 2018

\begin{tabular}{|c|c|c|c|c|}
\hline Desa & $\begin{array}{c}\text { Jumlah Hewan } \\
\text { Diperiksa }\end{array}$ & $\begin{array}{l}\text { Jumlah hewan Positif } \\
\text { Schistosomiasis }\end{array}$ & Prevalensi (\%) & Keterangan \\
\hline Dodolo & 31 & 2 & 6,5 & anjing, babi \\
\hline Kaduwa & 34 & 2 & 5,9 & anjing, sapi \\
\hline Tomehipi & 31 & 0 & 0 & \\
\hline Tuare & 30 & 0 & 0 & \\
\hline Tomado & 32 & 0 & 0 & \\
\hline Langko & 31 & 0 & 0 & \\
\hline Wanga & 10 & 1 & 10 & babi \\
\hline Alitupu & 10 & 0 & 0 & \\
\hline Winowanga & 12 & 0 & 0 & \\
\hline Anca & 20 & 0 & 0 & \\
\hline Lengkeka & 17 & 0 & 0 & \\
\hline Kageroa & 14 & 0 & 0 & \\
\hline
\end{tabular}


Tabel 3 menunjukkan prevalensi schistosomiasis antara desa bervariasi, sebagian besar desa prevalensi dibawah $1 \%$, namun beberapa desa prevalensi masih di atas $1 \%$ $(1,10-5,13 \%)$. Cakupan pengobatan massal pada manusia (penduduk minum obat dari jumlah sasaran) berkisar antara 58,8\% (Lengkeka) s/d 100\% (Kageroa, Wanga) dengan cakupan pengumpulan tinja berkisar antara 40,2\% (Langko) s/d 94,5\% (Tamadue).

Prevalensi schistosomiasis pada hewan ditemukan sebesar 10\%. Prevalensi schistosomiasis pada hewan paling tinggi ditemukan di Desa Wanga dengan prevalensi 10\%. Hewan yang ditemukan positif schistosomiasis adalah anjing, sapi, dan babi (Tabel 4). Untuk cakupan pengobatan massal pada hewan sebesar $0 \%$.

\section{PEMBAHASAN}

Penularan penyakit sangat dipengaruhi oleh lingkungan, seperti halnya schistosomiasis. Oleh karena itu, solusi untuk mengatasinya tidak hanya menjadi tanggung jawab sektor kesehatan saja. Kolaborasi antar sektor sangat diperlukan. ${ }^{7,8}$ Untuk menjawab tantangan ini, maka telah disusun roadmap kegiatan pengendalian schistosomosiasis 2018-2025 yang berisi kegiatan pengendalian schistosomiasis yang melibatkan banyak sektor di luar kesehatan. ${ }^{9}$

Akan tetapi, 53,6\% kegiatan pengendalian schistosomiasis yang direncanakan dalam roadmap tidak terlaksana pada tahun 2018. Kegiatan 2018 yang tidak terlaksana disebabkan oleh 1) penyusunan roadmap dilakukan pada akhir tahun 2017, sebaliknya kegiatan lintas sektor telah tersusun sebelumnya,2) pengendalian schistosomiasis bukan merupakan kegiatan prioritas di kementerian di luar Kementerian Kesehatan sehingga pada saat perencanaan kegiatan, menu kegiatan tidak terdapat dalam aplikasi,3) tidak ada kementerian yang secara khusus bertanggung jawab terhadap pelaksanaan roadmap eliminasi Schistosomiasis 2018-2025, serta4) sering terjadi pergantian pejabat lintas sektor baik di Kementerian Pusat dan OPD di daerah yang menyebabkan pelaksanaan roadmap belum berjalan dengan baik.
Lintas sektor berusaha mengatasi ini dengan cara mengalihkan beberapa lokasi kegiatan tahun 2018, seperti kegiatan pembuatan saluran air yang sebelumnya direncanakan di desa non-endemis dipindahkan ke desa endemis schistosomiasis. Walaupun 53,6\% kegiatan yang direncanakan dalam roadmap tidak terlaksana, beberapa lintas sektor yang sebelumnya tidak termasuk dalam roadmap, ikut terlibat adalah Dinas Pendidikan, Dinas Lingkungan Hidup, dan BWS III. dalam kegiatan pengendalian schistosomiasis di tahun 2018. Lintas sektor tersebut.

Pelaksanaan kegiatan pengendalian schistosomiasis di masing-masing sektor juga mengalami kendala. Beberapa kegiatan modifikasi lingkungan, seperti pembangunan irigasi maupun pembuatan kolam ikan tidak tepat mengenai sasaran daerah fokus. Ketidaktepatan pembangunan ini banyak disebabkan oleh masalah internal, baik dalam internal sektor maupun daerah target pembangunan fisik. Selain itu terdapat kegiatan yang dilaksanakan tidak sesuai dengan standar prosedur operasional (SPO), seperti kegiatan pembagian pot untuk survei tinja. Untuk pemeriksaan dengan KatoKatz, pembagian pot seharusnya 3 pot untuk 3 kali BAB (3 hari). Pada kenyataannya pot yg dibagi hanya 1 atau 2 pot. Hal ini mempengaruhi prevalensi schistosomiasis pada manusia.

Kunci keberhasilan pengendalian schistosomiasis yang melibatkan banyak sektor adalah dukungan, baik dari tingkat nasional, provinsi, kabupaten, bahkan sampai tingkat desa ${ }^{10}$. Dukungan politik yang kuat dan dukungan sumber daya yang ada menjadi kunci pelaksanaan pengendalian NTD termasuk schistosomiasis. Kesadaran bahwa keberhasilan dalam penanggulangan masalah kesehatan masyarakat akan berimbas positif pada penanggulangan masalah di sektor lain akan meningkatkan kemauan untuk melakukan tindakan pengendalian seperti halnya pengendalian schistosomiasis. ${ }^{11}$ Cina, Brazil, dan Mesir berhasil melakukan pengendalian schistosomiasis dengan dukungan politik dan kerjasama lintas sektor yang kuat. Berbagai sektor baik kesehatan, pertanian, peternakan, pendidikan, dan sektor lain bekerjasama melakukan pengendalian schistosomosiasis 
yang menurunkan prevalens dan bahkan memberikan dampak positif di bidang lain, seperti meningkatnya hasil pertanian ${ }^{11,12}$.

Di Indonesia, dukungan dari pusat maupun daerah mulai ditunjukkan dengan mulai dibuatnya Roadmap pengendalian schistosomiasis, yang ditandatangani oleh Menteri Bappenas dan Menteri Kesehatan dan disetujui oleh Kementerian lainnya. Menteri Kesehatan juga telah mengeluarkan PMK tentang eliminasi Schistosomiasis, yaitu PMK No. 19 Tahun 2018 yang harus menjadi dasar dalam kegiatan pengendalian schistosomiasis terutama oleh sektor kesehatan. Akan tetapi untuk pendanaan kegiatan oleh sektor di luar kesehatan, diperlukan Peraturan Presiden yang dapat dijadikan dasar untuk menjadikan pengendalian schistosomiasis sebagai salah satu kegiatan prioritas di sektor lain di luar kesehatan. Disamping itu, monitoring dan evaluasi menjadi hal yang sangat penting untuk menjamin pelaksanaan dan keberlangsungan (sustainability) pelaksanaan pengendalian schistosomiasis oleh lintas sektor. Perlu diadakan koordinasi rutin lintas sektor. Selain itu perlu disadari bahwa keberhasilan pelaksanaan antar daerah, baik antar kabupaten maupun antar desa, akan sangat bervariasi karena tergantung pada sosio-ekologi setempat maupun komitmen masing-masing daerah. ${ }^{10}$

Untuk mencapai eliminasi schistosomiasis diperlukan pendekatan pengendalian schistosomiasis yang terintegrasi dan didukung oleh peran serta masyarakat. Pengendalian schistosomiasis harus termasuk penyediaan air bersih, peningkatan sanitasi, pengendalian keong perantara, perubahan perilaku, dan ketersediaan obat. Selain itu dukungan dari berbagai pihak mulai dari tingkat nasional sampai masyarakat setempat di daerah endemis serta pengendalian yang melibatkan lintas sektor menjadi kunci utama pengendalian schistosomiasis yang berkelanjutan. ${ }^{13}$

Desa percontohan pengendalian schistosomiasis mencoba mewujudkan hal ini. Kegiatan pengendalian schistsosomiasis tidak hanya berupa kegiatan yang dilakukan oleh masing-masing lintas sektor dari kesehatan, pertanian, peternakan, PU, perikanan, maupun taman nasional akan tetapi berusaha melibatkan masyarakat di daerah endemis sebagai pelaku kegiatan pengendalian. Hotez dan Pecoul menyatakan bahwa untuk keberhasilan pengendalian NTD termasuk schistosomiasis tidak ada yang lebih penting dibandingkan keterlibatan masyarakat. ${ }^{14}$

Cina telah berhasil melakukan kegiatan pengendalian schistosomiasis di beberapa wilayah yang menjadi pilot project. Kegiatan pengendalian ini memperhitungkan faktor lingkungan dan sosio-ekonomi dan mendasarkan pada pemahaman bahwa epidemiologi schistosomiasis tidak hanya dipengaruhi oleh demografi dan sosial manusia, tetapi juga oleh keberadaan dan pergerakan hewan. Kegiatan pengendalian di Cina dititiberatkan pada mekanisasi pertanian, meningkatkan akses air bersih, sanitasi, manajemen hewan ternak, manajemen pembuangan tinja, dan edukasi masyarakat. ${ }^{15}$

Kegiatan pengendalian yang melibatkan masyarakat dengan pendekatan empowerment mengharapkan masyarakat dapat menentukan sendiri kegiatan apa yang baik mereka lakukan untuk melakukan pengendalian penyakit. ${ }^{14}$ Akan tetapi pemahaman masyarakat akan penyakit harus memadai untuk dapat memberikan ide dan melaksanakan kegiatan pengendalian. ${ }^{10}$

Di tiga desa percontohan, pengetahuan masyarakat tentang schistosomiasis terutama tentang penyebab, gejala, keong perantara, cara penularan, dan fokus keong perantara masih sangat kurang. Hal ini berusaha diatasi dengan memberikan edukasi tentang schistosomiasis kepada masyarakat umum dan anak sekolah secara terpisah. Masyarakat diperlihatkan langsung keong perantara Oncomelania hupensis lindoensis dan serkaria Schistosoma japonicum dengan harapan apabila mereka melihat langsung lebih mudah untuk terjadi perubahan perilaku. Hal ini terjadi di Cina dengan metode edukasi masyarakat dan anak sekolah yang tepat dapat mengurangi prevalensi kecacingan dan terjadi perubahan perilaku yang signifikan. ${ }^{10}$

Edukasi masyarakat tentang schistosomiasis ditujukan untuk memobilisasi masyarakat untuk berkontribusi pada pengendalian daerah fokus keong, terutama dengan kegiatan pengendalian yang berasal dari masyarakat sendiri. Ini sangat berguna karena tidak hanya untuk mengontrol schistosomiasis tetapi juga menciptakan masyarakat yang mendukung 
perbaikan kesehatan secara umum. ${ }^{13}$ Kegiatan partisipasi masyarakat dalam pengendalian schistosomiasis di desa percontohan diawali dengan melakukan Focus Group Discussion (FGD) dengan anggota masyarakat untuk mengetahui kegiatan apa yang bisa mereka lakukan untuk pengendalian schistosomiasis. Di Desa Dodolo, Napu dan Tomado, Lindu, masyarakat mengganggap penting adanya aturan adat atau aturan desa untuk mengatur keterlibatan masyarakat. Kedua desa ini sudah sangat lama terpapar dengan schistossomiasis dan masyarakatnya mulai menunjukkan sikap apatis terhadap kegiatan pengendalian schistosomiasis sehingga mereka mengganggap perlu adanya aturan yang mengikat masyarakat. Aturan adat dan aturan desa ini sampai saat ini masih dalam proses penyusunan dan pembahasan. Di Desa Tomehipi, Bada, resistensi masyarakat menurun setelah mereka menerima edukasi tentang schistosomiasis. Pentingnya edukasi terlihat dengan terbukanya masyarakat untuk kegiatan pengendalian yang bersifat mandiri. Masyarakat di Desa Tomehipi pada akhirnya mengusulkan pelaksanaan kegiatan pembersihan daerah fokus setiap bulannya. Kegiatan ini kemudian disambut oleh Dinas Kesehatan Kabupaten dengan mencarikan sektor lain yang dapat membiayai pengadaaan sepatu boot untuk membantu masyarakat dalam kegiatan pembersihan. Pada akhirya kegiatan ini berkembang menjadi dua kali sebulan dan diberi nama GEMA-BERAKSI (Gerakan Masyarakat Mandiri Berantas Keong Schistosomiasis).

\section{KESIMPULAN}

Hanya 53,6\% kegiatan yang direncanakan dalam roadmap tidak terlaksana pada tahun 2018. Perbandingan jumlah fokus yang ditemukan pada akhir tahun 2018 tidak terlalu jauh berbeda dengan sebelum kegiatan pengendalian. Perbedaan jumlah fokus lebih disebabkan karena keringnya daerah fokus yang disebabkan oleh cuaca. Prevalensi schistosomiasis pada manusia tahun 2018 berkisar $0-5,1 \%$. Prevalensi schistosomiasis pada hewan berkisar $0-10 \%$.

Peranan aktif kelompok kerja tim pengendalian scchistosomiasis perlu ditingkatkan dengan Bappeda sebagai leading sector.

\section{UCAPAN TERIMA KASIH}

Penulis mengucapkan terima kasih kepada seluruh lintas sektor yang telah melakukan kegiatan pemberantasan schistosomiasis. Terima kasih pula untuk kepala desa di desa percontohan dan kontrol serta seluruh masyarakat desa yang telah aktif terlibat dalam kegiatan pengendalian schistosomiasis.

\section{DAFTAR RUJUKAN}

1. Dinas Kesehatan Propinsi Sulawesi Tengah. Prevalensi Schistosomiasis di Sulawesi Tengah. Progam Pemberantasan Schistosomiasis. Palu: Dinas Kesehatan Provinsi Sulawesi Tengah; 2012.

2. WHO. Assessment of The National Schistosomiasis Control Programme in Indonesia. Geneva: World Health Organization;2012.

3. Jastal, Garjito TA, Anastasia H, Mujiyanto, Chadijah S. Analisis spasial epidemiologi schistosomiasis menggunakan penginderaan jauh dan sistem informasi geografis di Sulawesi Tengah. Donggala: Balai Litbang P2B2 Donggala;2008.

4. Dinas Kesehatan Provinsi Sulawesi Tengah. Laporan Schistosomiasis. 2016. Palu: Dinas Kesehatan Provinsi Sulawesi Tengah;2016.

5. Gunawan, Anastasia H, Pamela P, Risti. Laporan Akhir Penelitian Kontribusi Reservoir dalam Penularan Schistosomiasis di Kecamatan Lindu Kabupaten Sigi Propinsi Sulawesi Tengah Tahun 2013. Donggala: Balai Litbang P2B2 Donggala;2013.

6. Gunawan, Anastasia H, Pamela $\mathrm{P}$, Risti. Kontribusi Hewan Mamalia Sapi, Kerbau, Kuda, Babi, dan Anjing dalam Penularan Schistosomiasis di Kecamatan Lindu Kabupaten Sigi Propinsi Sulawesi Tengah Tahun 2013. Media Litbangkes. 2014;24(4):209-214.

7. Utzinger J, N'Goran EK, Caffrey CR, Keiser J. From innovation to application: Socialecological context, diagnostics, drugs and integrated control of schistosomiasis. Acta Tropica. 2011:121-137.

8. Ehrenberg JP, Ault SK. Neglected diseases of neglected populations: Thinking to reshape the determinants of health in Latin America 
and the Caribbean. BMC Public HEalth. 2005;5(119):1-13.

9. Anastasia H, Widjaja J. Engaging multi-sectoral collaboration to combat schistosomiasis in Napu highlands, Poso District, Central Sulawesi. Journal of Physics: Conference Series. 2019;1155:1-9.

10. Editorial. A New Global Strategy for The Elimination of Schistosomiasis. International Journal of Infectious Disease. 2017;54:130-137.

11. Chitsulo L, Engels D, Montresor A, Savioli L. The Global Status of Schistosomiasis and its Control. PMC. 2017(October).

12. Utzinger J, N'Goran EK, Caffrey CR, Keiser J. From innovation to application: Socialecological context, diagnostics, drugs and integrated control of schistosomiasis. Acta Tropica. 2011:S121-S137.
13. Karunamoorthi K, Almalki MJ, Ghailan KY. Schistosomiasis: A Neglected Tropical Disease of Poverty: A Call for Intersectoral Mitigation Strategies for Better Health. Journal of Health Research and Reviews 2018;5:1-12.

14. Marchal B, Dormael Mv, Pirard M, Cavalli A, Kegels G, Polman K. Neglected tropical disease (NTD) control in health systems: The interface between programmes and general health services. Acta Tropica. 2011:S177-S185.

15. Wang L-D, Guo J-G, Wu X-H, et al. China's new strategy to block Schistosoma japonicum transmission: experiences and impact beyond schistosomiasis. Tropical Medicine and International Health 2009;14(12):14751483. 